\title{
EFFECTS OF STABILISED NITROGEN FERTILIZERS IN OILSEED RAPE (BRASSICA NAPUS L.) NUTRITION
}

\author{
Dominika Mikusovaํㅗ ${ }^{\text {Pavel Ryant }}{ }^{1}$ \\ ${ }^{1}$ Department of Agrochemistry, Soil Science, Microbiology and Plant Nutrition, Faculty of AgriSciences, Mendel \\ University in Brno, Zemědělská 1, 61300 Brno, Czech Republic
}

Link to this article: https://doi.org/10.11118/actaun.2021.028

Received: 14. 3. 2021, Accepted: 8. 4. 2021

To cite this article: MIKUSOVA DOMINIKA, RYANT PAVEL. 2021. Effects of Stabilised Nitrogen Fertilizers in Oilseed Rape (Brassica napus L.) Nutrition. Acta Universitatis Agriculturae et Silviculturae Mendelianae Brunensis, 69(2): 291-298.

\begin{abstract}
The aim of this study was to evaluate the effects of added nitrification inhibitor (NI) and urease inhibitor (UI) to urea ammonium nitrate (UAN) on oilseed rape yield and seed oil content in 3-year field trials and to assess their environmental impact by analysing the content of nitrates in water extracts in the form of soil laboratory experiments. The UAN stabilisation was provided by the addition of PIADIN (1.5\% methylpyrazole, 3\% triazole) serving as NI and StabilureN (NBPT) used as UI. The experiment consisted of four variants: 1. UAN; 2. UAN + NI; 3. UAN + UI; 4. UAN + NI + UI.

The obtained data showed the increased rates of the yield and seed oil content in the variants with the NI/UI additions in one experimental year. Statistically significant differences were detected in the yield and seed oil content obtained between the years of the experiment. Soil laboratory experiments proved that the additions of both inhibitors (UAN + NI + UI) led to the least leaching of nitrates.
\end{abstract}

Keywords: nitrogen fertilizers, urease inhibitors, nitrification inhibitors, oilseed rape, yield, oil content, nitrogen leaching

\section{INTRODUCTION}

The presence of nitrogen in the soil determines the course of crop vegetation, their yield, and seed quality. Plants take up nitrogen directly by their roots in mineral forms as $\mathrm{NH}_{4}^{+}$and $\mathrm{NO}_{3}^{-}$- these forms are therefore the components of most mineral $\mathrm{N}$ fertilizers (Spinelli et al., 2013). On the other hand, the use of conventional mineral $\mathrm{N}$ fertilizers (due to emissions of $\mathrm{NH}_{3}, \mathrm{NO}_{\mathrm{x}}$ and $\mathrm{NO}_{3}^{-}$leaching) results in losses of nitrogen from the soil. These losses decrease soil fertility, but also present a risk to the atmosphere, hydrosphere, and human health as well (Cameron et al., 2013; Ju et al., 2006).

The fertilizer industry faces a continuing challenge to improve its products to increase the efficiency of their use (particularly of nitrogenous fertilizers) and to minimize any possible adverse environmental impact (Trenkel, 2010). This improvement (and thus reduction of nitrogen losses) may be provided by the use of stabilized nitrogen fertilizers containing nitrification or/and urease inhibitors. The process of ammonium oxidation (nitrification) is divided into two degrees - the first degree of oxidation $\left(\mathrm{NH}_{4}^{+} \rightarrow \mathrm{NO}_{2}^{-}\right)$is carried out by chemoautotrophic bacteria of the genera Nitrosomonas, Nitrosovibria, Nitrosospira and Nitrococus. The second degree of oxidation $\left(\mathrm{NO}_{2}^{-} \rightarrow \mathrm{NO}_{3}^{-}\right.$) is provided by genera Nitrobacter and Nitrosolobus (Singh and Verma, 2007). The principle of nitrification inhibitors is to control losses of nitrogen, thus increasing its efficacy by keeping $\mathrm{N}$ in its ammoniacal form for the longer period (4-10 weeks). This is provided by decreasing the activity of bacteria participating in the first stage of ammonium oxidation (Edmeades, 2004).

The main principle of the effect of urease inhibitors is to partial inhibition of the urease activity, therefore the delay of hydrolysis of urea to the final product - ammonia (entering to nitrification process) and the reduction of $\mathrm{NH}_{3}$ losses by its volatilization (Trenkel, 2010). 
This paper is focused on evaluating the suitability of liquid nitrogen fertilizer urea ammonium nitrate (UAN) and its combinations with nitrification inhibitors and urease inhibitors in the oilseed rape nutrition.

\section{MATERIALS AND METHODS}

The aim of this study was divided in two categories:

1. To assess the effects of the added inhibitors on the yield, seed oil content in 3-year field trials.

2. To assess an environmental impact of added inhibitors in form of soil laboratory experiments by analysing the content of $\mathrm{NO}_{3}^{-}$in water extracts.

\section{Field Trials}

The 3-year field trials were carried out in the system of random blocks (up to $15 \mathrm{~m}^{2}$ ) in four repetitions in Field Trial Station Žabčice (N 49¹.37702', E 16³7.07360'). This station is in the South Moravian dry area (annual rainfall of $480 \mathrm{~mm}$, average annual temperature of $9.2^{\circ} \mathrm{C}$, fluvial soil type). The winter rape variety named DK Exception was selected for this study.

To assess the effects of NI and UI added to liquid nitrogen fertilizers UAN, four variants were chosen (see Tab. I). PIADIN (1.5\% methylpyrazole, $3 \%$ triazole) as a nitrification inhibitor and StabilureN (NBPT) as a urease inhibitor were used to stabilize the UAN fertilizer.

I: Variants and doses of fertilizers

\begin{tabular}{llcc}
\hline & Variants & Fertilization in phase of rosette & Fertilization in phase of stem elongation \\
\hline 1 & UAN & LAS $(64 \mathrm{~kg} \mathrm{~N} / \mathrm{ha})$ & UAN (130 kg N/ha) \\
2 & UAN + NI & LAS $(64 \mathrm{~kg} \mathrm{~N} / \mathrm{ha})$ & UAN + NI (130 kg N/ha) \\
3 & UAN + UI & LAS $(64 \mathrm{~kg} \mathrm{~N} / \mathrm{ha})$ & UAN + UI (130 kg N/ha) \\
4 & UAN + NI + UI & LAS (64 kg N/ha) & UAN + NI + UI (130 kg N/ha) \\
\hline
\end{tabular}

Legend: NI - nitrification inhibitor; UI - urease inhibitor; UAN (30\% N); LAS (24\% N and 5.6\% S - mixture of ammonium nitrate with calcium sulphate)

II: Terms of sowing, application of fertilizers and harvest

\begin{tabular}{lcccc}
\hline $\begin{array}{c}\text { Year } \\
\text { of the experiment }\end{array}$ & Sowing & $\begin{array}{c}\text { Fertilization } \\
\text { in phase of rosette }\end{array}$ & $\begin{array}{c}\text { Fertilization in phase } \\
\text { of stem elongation }\end{array}$ & Harvest \\
\hline 2017 & 25 August 2016 & 10 March 2017 & 31 March 2017 & 8 July 2017 \\
2018 & 17 August 2017 & 5 March 2018 & 9 April 2018 & 2 July 2018 \\
2019 & 23 August 2018 & 28 February 2019 & 29 March 2019 & 10 July 2019 \\
\hline
\end{tabular}

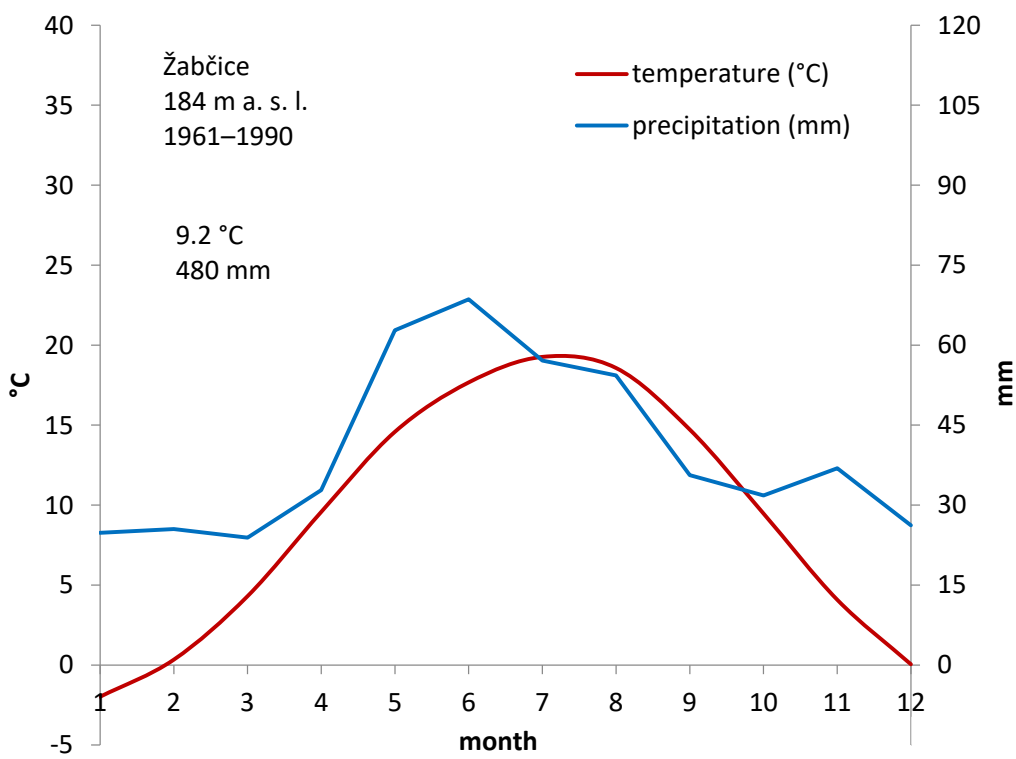

1: Diagram of average temperatures and sums of precipitation in the long-term normal 1961-1990 in Žabčice 
III: Monthly sums of precipitation and monthly means of air temperature compared with the long-term normal 1961-1990

\begin{tabular}{|c|c|c|c|c|c|c|c|c|c|c|c|c|}
\hline \multirow{3}{*}{$\begin{array}{l}\text { Months } \\
\text { I }\end{array}$} & \multicolumn{6}{|c|}{ Precipitation [mm] } & \multicolumn{6}{|c|}{ Average temperature $\left[{ }^{\circ} \mathrm{C}\right]$} \\
\hline & \multicolumn{2}{|c|}{2017} & \multicolumn{2}{|c|}{2018} & \multicolumn{2}{|c|}{2019} & \multicolumn{2}{|c|}{2017} & \multicolumn{2}{|c|}{2018} & \multicolumn{2}{|c|}{2019} \\
\hline & 32.1 & AN & 46.2 & SAN & 27.0 & $\mathrm{~N}$ & -5.8 & $\mathrm{BN}$ & 2.1 & SAN & -0.9 & $\mathrm{~N}$ \\
\hline II & 10.7 & $\mathrm{BN}$ & 14.5 & $\mathrm{BN}$ & 24.4 & $\mathrm{~N}$ & 1.5 & $\mathrm{~N}$ & -1.9 & $\mathrm{BN}$ & 2.4 & $\mathrm{~N}$ \\
\hline III & 18.7 & $\mathrm{~N}$ & 15.6 & $\mathrm{~N}$ & 12.6 & $\mathrm{~N}$ & 7.7 & SAN & 2.4 & $\mathrm{~N}$ & 7.0 & AN \\
\hline IV & 42.4 & $\mathrm{~N}$ & 9.6 & SBN & 19.2 & $\mathrm{BN}$ & 8.9 & $\mathrm{~N}$ & 14.6 & EAN & 11.8 & AN \\
\hline V & 24.0 & SBN & 51.2 & $\mathrm{~N}$ & 79.0 & $\mathrm{~N}$ & 15.8 & $\mathrm{~N}$ & 18.3 & EAN & 12.6 & BN \\
\hline VI & 25.8 & SBN & 45.6 & $\mathrm{BN}$ & 67.2 & $\mathrm{~N}$ & 20.8 & EAN & 20.1 & SAN & 22.8 & EAN \\
\hline VII & 68.2 & $\mathrm{~N}$ & 36.0 & $\mathrm{~N}$ & 55.4 & $\mathrm{~N}$ & 21.1 & SAN & 21.8 & EAN & 21.0 & SAN \\
\hline VIII & 22.4 & $\mathrm{BN}$ & 14.2 & SBN & 72.4 & AN & 21.7 & EAN & 23.8 & EAN & 21.7 & EAN \\
\hline IX & 83.0 & SAN & 114.8 & EAN & 46.0 & $\mathrm{~N}$ & 14.1 & $\mathrm{~N}$ & 16.6 & AN & 15.6 & $\mathrm{~N}$ \\
\hline $\mathrm{X}$ & 35.8 & $\mathrm{~N}$ & 10.2 & $\mathrm{BN}$ & 35.0 & $\mathrm{~N}$ & 10.4 & $\mathrm{~N}$ & 12.0 & SAN & 10.6 & AN \\
\hline XI & 23.8 & $\mathrm{~N}$ & 11.6 & SBN & 38.0 & $\mathrm{~N}$ & 4.6 & $\mathrm{~N}$ & 5.8 & SAN & 7.2 & EAN \\
\hline XII & 20.4 & $\mathrm{~N}$ & 28.6 & $\mathrm{~N}$ & 46.0 & AN & 1.4 & $\mathrm{~N}$ & 1.5 & $\mathrm{~N}$ & 1.7 & $\mathrm{~N}$ \\
\hline
\end{tabular}

Legend: $N$ - normal; $A N$ - above normal; $B N$ - below normal; SAN - strongly above normal; SBN - strongly below normal; EAN-extremely above normal

IV: Dates of experimental phases

\begin{tabular}{ccccc}
\hline \multirow{2}{*}{$\begin{array}{c}\text { Application } \\
\text { of the fertilizers }\end{array}$} & \multicolumn{4}{c}{ Collection of water extracts } \\
\cline { 2 - 5 } & $1^{\text {st }}$ & $2^{\text {nd }}$ & $3^{\text {rd }}$ & $4^{\text {th }}$ \\
\hline 1 July 2019 & 8 July 2019 & 15 July 2019 & 22 July 2019 & 29 July 2019 \\
\hline
\end{tabular}

The collections of soil samples (served for the evaluation purposes of mineral nitrogen content) were provided each year on the day of the harvest.

Seed oil content was gravimetrically determined according to the methodology by Zbíral et al. (2015) extracting the samples with diethylether solvent on suitable apparatus and distilling off the solvent and drying extracted fat of the sample.

The content of mineral nitrogen $\left(\mathrm{NO}_{3}^{-}\right.$and $\left.\mathrm{NH}_{4}^{+}\right)$ was analysed according to the methodology by Zbíral et al. (2017). The content of $\mathrm{NH}_{4}^{+}$was measured spectrophotometrically. The determination of $\mathrm{NO}_{3}^{-}$ content was carried out by the ISE (Ion-selective electrode) method.

The effects of inhibitors and years on winter rape yield and seed oil content were analysed via ANOVA analysis of variance followed by testing at 95\% ( $\mathrm{P}<0.05)$ level of significance using Tukey's HSD test (Statistica CZ 12 programme).

\section{Laboratory Experiment}

The soil laboratory experiment was performed to simulate the efficiency of nitrogen stabilization by selected NI and UI. The experiment was carried out in the form of precise pot trials (3 repetitions). Each pot was filled with $1.5 \mathrm{~kg}$ of soil (sampled from Field Trial Station Žabčice). The variants of fertilization were the same as in the field trials. Doses of fertilizers were converted to the surface of a pot (Tab. I).
The experiment took place in controlled laboratory conditions of Mendel University in Brno for the period of 4 weeks. The pots were watered to keep the soil moisture content above its maximum soil capacity. The water flowing through the pots was retained in the containers placed on stands under the pots. These water extracts were used for the analysis of the content of $\mathrm{NO}_{3}^{-}$. The collection of samples proceeded once a week. The determination of $\mathrm{NO}_{3}^{-}$was carried out by the ISE (Ion-selective electrode) method. The term overview of the experimental phases is shown in Tab. IV.

\section{RESULTS AND DISCUSSION}

\section{Field Trials}

It is clear from the data in the Tab. $\mathrm{V}$ that the addition of inhibitors to UAN did not significantly affect seed yield. Their positive effect was visible only in year 2019 in the variants No. 2 (UAN + NI) and No. 4 (UAN + NI + UI). NBPT proves a relatively short period of effective urease inhibition in soils according to Trenkel (2010). Cantarella et al. (2018) claim in their review article that despite hight NBPT potential in reducing $\mathrm{NH}_{3}$ losses from soil, its effect on crop yield is much more limited and, in most studies, the yield increase ranges from 5 to $12 \%$. Low effect of NBPT on crop yield is also described in the article by Viero et al. (2017). 
V: Average yields of winter rape seeds and the significance of their differences between the variants of fertilization

\begin{tabular}{|c|c|c|c|c|c|}
\hline & \multirow{2}{*}{ Variants } & \multicolumn{3}{|c|}{ Yield $[\mathrm{t} / \mathrm{ha}] \pm$ standard deviation } & \multirow{2}{*}{$\begin{array}{c}\text { Yield [t/ha] } \\
\text { averages }\end{array}$} \\
\hline & & 2017 & 2018 & 2019 & \\
\hline 1 & UAN & $3.47^{\mathrm{a}} \pm 0.67$ & $4.78^{\mathrm{a}} \pm 0.05$ & $4.54^{a} \pm 0.43$ & $4.26^{\mathrm{a}}$ \\
\hline 2 & $\mathrm{UAN}+\mathrm{NI}$ & $3.12^{\mathrm{a}} \pm 0.51$ & $4.65^{\mathrm{a}} \pm 0.06$ & $4.64^{\mathrm{a}} \pm 0.34$ & $4.13^{\mathrm{a}}$ \\
\hline 3 & $\mathrm{UAN}+\mathrm{UI}$ & $3.47^{\mathrm{a}} \pm 0.23$ & $4.73^{a} \pm 0.33$ & $4.47^{a} \pm 0.26$ & $4.22^{\mathrm{a}}$ \\
\hline 4 & $\mathrm{UAN}+\mathrm{NI}+\mathrm{UI}$ & $3.47^{\mathrm{a}} \pm 0.29$ & $4.74^{\mathrm{a}} \pm 0.19$ & $4.62^{\mathrm{a}} \pm 0.34$ & $4.27^{\mathrm{a}}$ \\
\hline
\end{tabular}

Legend: Averages are significantly different if they have different letters

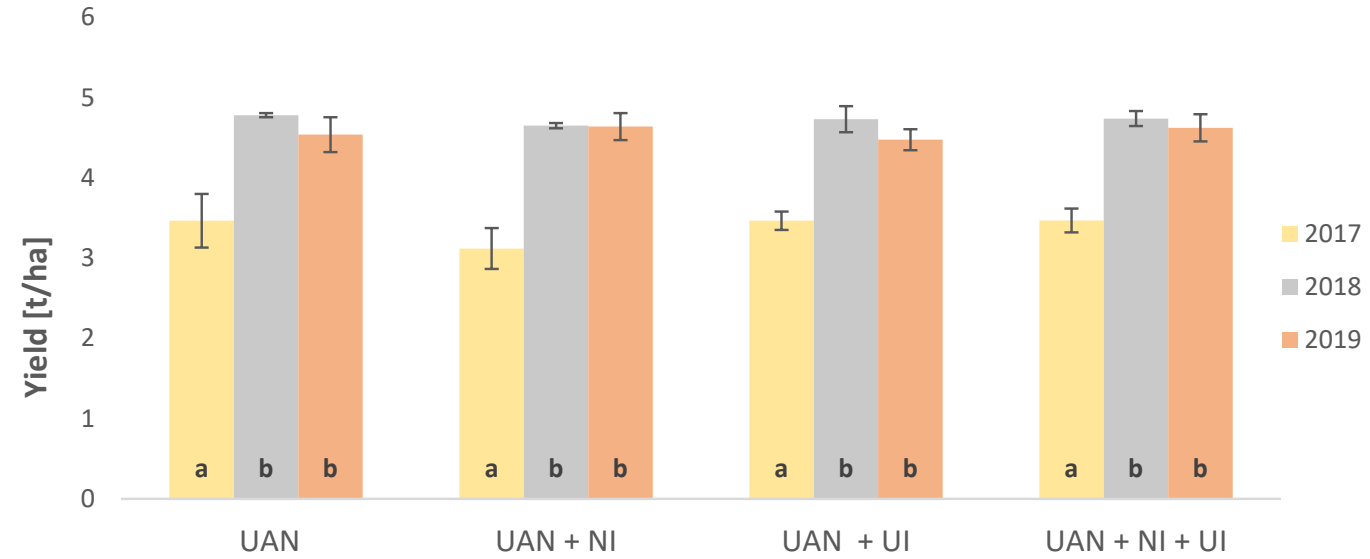

2: Average yields of winter rape seeds and the significance of their differences between observation years

Other important factor of NBPT efficiency is soil moisture. The data of the average precipitation and temperature rates (see Tab. III) show that April (month of/after UI application) in 2018 and 2019 showed lower precipitations (SBN in 2018; BN in 2019; see Tab. III) and higher temperature rates (EAN in 2018; AN in 2019; see Tab. III) in the comparison to the long-term normal values. Low contents of soil moisture and higher temperatures during critical days after the UI application could show the effect on the decreased efficiency of UI in the terms of the yield. The increasing efficiency of NBPT with the increasing levels of irrigation is described in the article by Sanz-Conbena et al. (2011).

The effect of NI is also limited by the lack of precipitation (Balík and Černý, 2020). The temperature is also crucial for the NI efficiency. Many inhibitors are already biologically and physically unstable at temperatures above $15^{\circ} \mathrm{C}$ (Vilsmeier, 1980). Higher rapeseed yields after the NI application were documented in the literature (eg. Wozniak et al., 1999). A comprehensive study in Germany concluded that nitrification inhibitors do not always increase yields but the reduced number of fertilizer applications allows great flexibility in the timing of fertilizer applications, which is especially important in times of changing climate (Hu et al., 2014).

No statistically significant differences were detected between the variants in each year of the experiment according to the analysis by Tukey's test $(\mathrm{P}<0.05)$. Statistically significant differences in rapeseed yields were visible only between the monitored years. The yields in 2018 and 2019 were determined significantly higher than in 2017 (Fig. 2). This difference could be explained as the result of significantly different weather course during the years of experiment.

The year 2017 with lower precipitation (especially in the duration from April to June) was significantly proved than in the years of 2018 and 2019 according to the comparison shown in Tab. III. These data correspond to the findings of Danesh-Shahraki et al. (2008) showing that rapeseed is the most sensitive to water deficit during the period of flowering and early ripening. The similar effect was observed in our experiment that means a negative effect on the yield and seed oil content.

As can be seen in Tab. VI, the addition of NI and UI to UAN was not significantly reflected in the oil content of the rapeseed. A slightly positive effect can be observed only in 2019, when the highest oil content was found in the variant No. 3 (UAN + UI). This result corresponds with the findings by Grant et al. (2011). The general assumption was that the increased N uptake from soil by plants in 2019 (and thus the increased yield) manifested in lower contents of $\mathrm{N}_{\min }$ in soil samples (see Fig. 4) can lead to the decreased seed oil contents. According to Öztürk (2010), N is the major constituent of protein so it might increase the percentage of seed protein proving the inverse relationship with the oil 
VI: Average winter rape seed oil content and the significance of their differences between the variants of fertilization

\begin{tabular}{llcccc}
\hline & \multirow{2}{*}{ Variants } & \multicolumn{2}{c}{ Seed oil content [\%] \pm standard deviation } & Seed oil content [\%] \\
\cline { 3 - 6 } & & 2017 & 2018 & 2019 & $49.9^{\mathrm{a}} \pm 1.55$ \\
\hline 1 & $\mathrm{UAN}$ & $40.1^{\mathrm{a}} \pm 1.74$ & $41.4^{\mathrm{a}} \pm 0.37$ & $40.4^{\mathrm{a} \pm 1.33}$ & $40.9^{\mathrm{a}}$ \\
\hline 2 & $\mathrm{UAN}+\mathrm{NI}$ & $40.1^{\mathrm{a}} \pm 1.42$ & $41.1^{\mathrm{a}} \pm 0.26$ & $40.6^{\mathrm{a}} \pm 1.24$ & $40.3^{\mathrm{a}}$ \\
\hline 3 & $\mathrm{UAN}+\mathrm{UI}$ & $39.1^{\mathrm{a}} \pm 0.83$ & $41.3^{\mathrm{a}} \pm 0.40$ & $40.4^{\mathrm{a}} \pm 0.73$ & $40.4^{\mathrm{a}}$ \\
\hline
\end{tabular}

Legend: Averages are significantly different if they have different letters

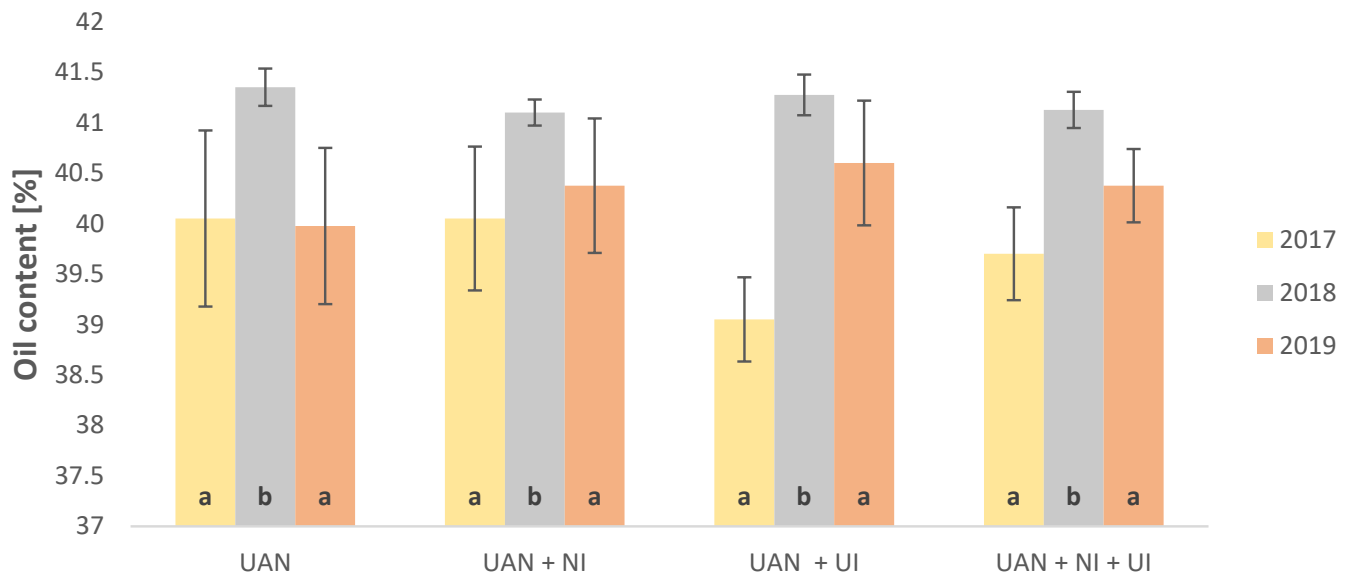

3: Average winter rape seed oil content and the significance of their differences between the observation years

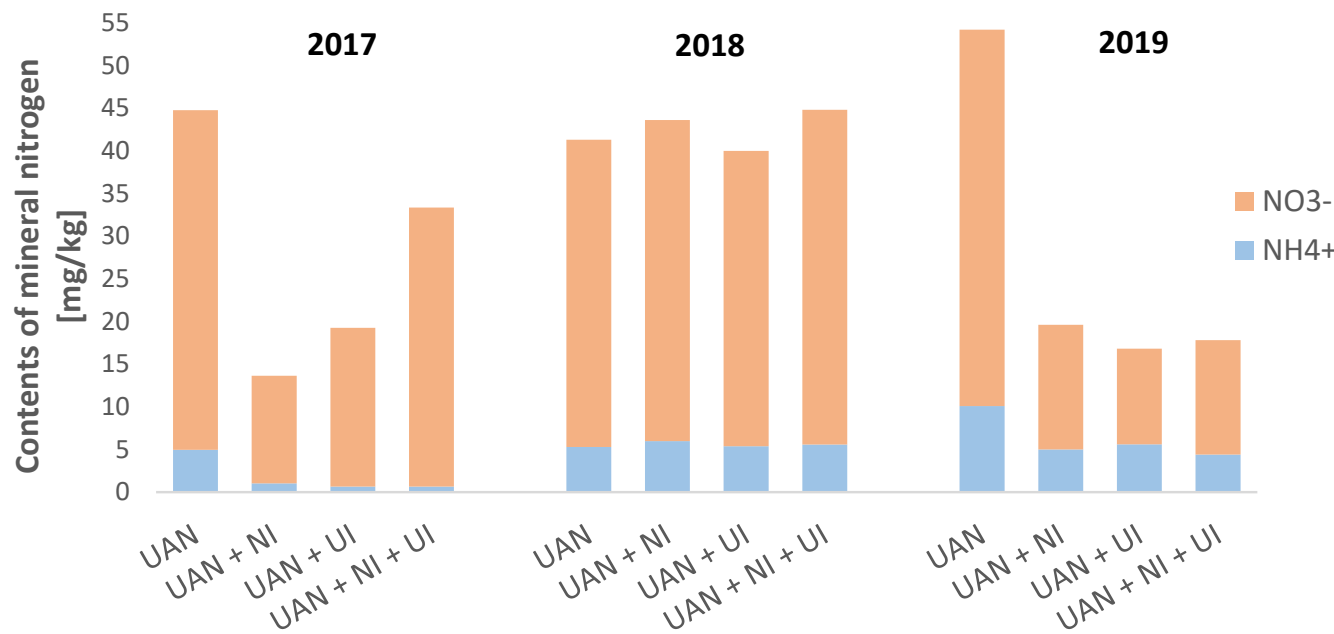

4: Mineral nitrogen content in the soil after winter rapeseed harvest

content. On the contrary, our findings showed that the oil content was not affected by possible higher $\mathrm{N}$ uptake which corresponded with the findings by Mirzashahi et al. (2010) and Dreccer et al. (2000).

The lowest oil content in rapeseed was found in 2017 showing a low content of mineral nitrogen after harvest (see Fig. 4). Low oil contents in 2017 might also be the results of possible drought stress (see Tab. III) confirmed by the findings of Elferjani and Soolanayakanahally (2018). Balík et al. (1998) detected that water stress can lead to the increased content of nitrogen reducing seed oil content.
No statistically significant differences can be concluded between the variants in each year of the experiment according to the analysis by Tukey's test $(\mathrm{P}<0.05)$. As in the case of seed yields, statistical differences were detected in the oil content in rapeseed between the observed years. Significantly higher oil content of seeds was achieved in 2018 (see Fig. 3).

The mineral nitrogen content in the soil after rapeseed harvest differed between the variants and the experimental years (see Fig. 4). Lower contents of mineral nitrogen determined in the variants with 


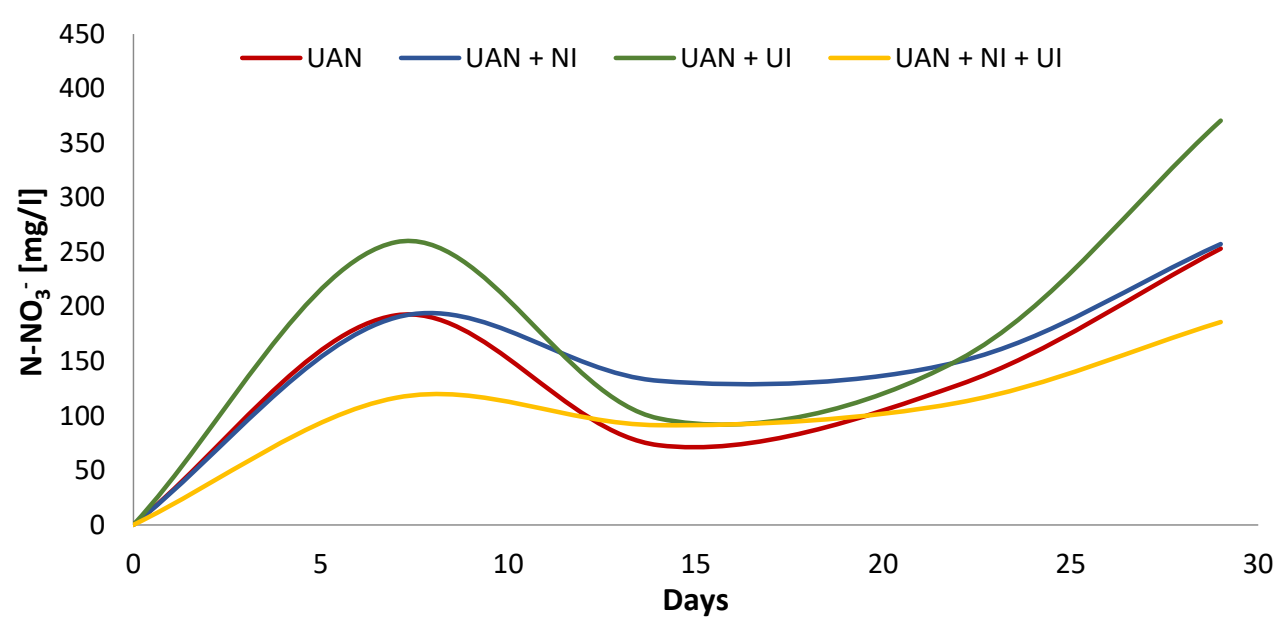

5: Dynamics of nitrate nitrogen leaching from the soil

the inhibitors were found in 2017 and 2019. More favourable conditions for the action of inhibitors can be concluded according to comparable yields especially in 2019 and 2018. In all variants, the proportion of nitrate nitrogen was detected in higher level than ammonium.

\section{Soil Laboratory Experiment}

The environmental impact of UAN stabilised with the additions of IN and IU was studied in the form of soil laboratory experiments. The contents of $\mathrm{NO}_{3}^{-}$ were analysed and thus its leaching potential in retained water flowing through the soil in the pots. The experiments were carried out in plant-free pots filled with soil identical to the soil from Field Trial Station Žabčice. The assumption was that the NI and UI effects could be more visible because of no effects of other factors.

The expectation was that the highest nitrogen release and therefore the highest leaching potential could be recorded in non-stabilised variant. The addition of inhibitors can affect the curve of $\mathrm{NO}_{3}^{-}$leaching and might gain the form of higher moderate increase. As predicted, the most moderate curve (the lowest rate of leached $\mathrm{NO}_{3}^{-}$at the same time) was obtained in the variant No. 4 (UAN + NI + UI) with the addition of both inhibitors. The efficiency of NI and UI is described in the article by Zaman et al. (2008) detected the combination of both inhibitors with urea decreasing the leaching of nitrates by $89 \%$.

On the contrary, the variants with the addition of one inhibitor expressed less efficiency than predicted. The data show the rates of leached nitrates higher than in control variant. The highest $\mathrm{NO}_{3}^{-}$concentrations (thus the highest leaching potential) were observed in the variant No. 3 with the addition of UI. Low efficiency of NI/UI additions to $\mathrm{N}$ fertilizers in regard to nitrate leaching is also described in the articles by Pawlik et al. (2019) and Mateo-Marín et al. (2020). Other record of the increased leaching potential of $\mathrm{NO}_{3}^{-}$after the addition of the inhibitors was described in the article by Sanz-Cobena et al. (2012) reported the increase by $33 \%$ in the leaching of $\mathrm{NO}_{3}^{-}$after the IN and IU addition to urea by 33\%.

\section{CONCLUSION}

The results showed that the additions of NI and UI to UAN did not prove significant positive effect on yield rates and seed oil content. The increased yield rates caused by the NI and UI additions were recorded in 2019 in the variant No. 4 (UAN + NI + UI) proved as the most effective. The increased percentage of seed oil content was also recorded in 2019 in the variant No. 3 (UAN + UI) proved as the most effective. Statistically significant differences were detected in yield and seed oil content obtained after the data comparison between the years of the experiment but not between the variants of each year. The assumption is that the differences between the years in yield rates and oil contents might be the result of their different weather course (mainly precipitation rate) during the time of rapeseed's flowering and early ripening (April-June). Taking into account the climatic conditions of Field Trial Station Žabčice, the conclusion could be that UAN stabilisation by the additions of nitrification inhibitor (PIADIN) and urease inhibitor (StabilureN) in the context of yield rates and seed oil contents was proved to be ineffective.

Positive effects of NI and UI additions were determined in the case of mineral nitrogen contents in the soil samples carried out in the years of 2017 and 2019. In these years, the variants with the additions of inhibitors (compared to the control one) showed the significant decrease in the content of mineral nitrogen. 
The evaluation of $\mathrm{NO}_{3}^{-}$leaching analysed from the samples of water extracts in soil laboratory experiments showed as the most effective variant with the addition of both inhibitors. The highest $\mathrm{NO}_{3}^{-}$concentrations (thus the highest leaching potential) were detected in the variant No. 3 with the addition of UI.

Aknowledgements

The research was supported by grant No. FA-IGA2019-IP037.

\section{REFERENCES}

BALÍK, J. et al. 1998. Nitrogen nutrition of winter oilseed rape. Agrochémia, 38(3): 11-13.

BALÍK, J., ČERNÝ, J. 2020. Perspektivy využití inhibitorů ureázy a inhibitorů nitrifikace. Úroda, 68(3): 88-92.

CAMERON, K. C., DI, H. J. and MOIR, J. L. 2013. Nitrogen losses from the soil/plant system: A review. Annals of Applied Biology, 162(2): 145-173.

CANTARELLA, H., OTTO, R., SOARES, J. R. et al. 2018. Agronomic efficiency of NBPT as a urease inhibitor: A review. Journal of Advanced Research, 13: 19-27.

DANESH-SHAHRAKI, A., NADIAN, H., BAKHSHANDEH, A. et al. 2008. Optimization of Irrigation and Nitrogen Regimes for Rapeseed Production Under Drought Stress. Journal of Agronomy, 7: 321-326.

DRECCER, M. F., SCHAPENDONK, A. H. C. M., SLAFER, G. A. et al. 2000. Comparative response of wheat and oilseed rape to nitrogen supply: absorption and utilisation efficiency of radiation and nitrogen during the reproductive stages determining yield. Plant Soil, 220(1): 189-205.

EDMEADES, D. C. 2004. Nitrification and urease inhibitors: A review of the national and international literature on their effects on nitrate leaching, greenhouse gas emissions and ammonia volatilisation from temperate legume - based pastoral systems. Environment Waikato Technical Report 2004/22. Waikato.

ELFERJANI, R. and SOOLANAYAKANAHALLY, R. 2018. Canola Responses to Drought, Heat, and Combined Stress: Shared and Specific Effects on Carbon Assimilation, Seed Yield, and Oil Composition. Frontiers in Plant Science, 9: 1224.

GRANT, C. A., DERKSEN, D. A., MCLAREN, D. L. et al. 2011. Nitrogen fertilizer and urease inhibitor effects on canola seed quality in a one-pass seeding and fertilizing system. Field Crops Research, 121: 201-208.

HU, Y., SCHRAML, M., VON TUCHER, S., LI, F. and SCHMIDHALTER, U. 2014. Influence of nitrification inhibitors on yields of arable crops: A meta-analysis of recent studies in Germany. International Journal of Plant Production, 8(1): 33-50.

JU, X. T., KOU, C. L., ZHANG, F. S. et al. 2006. Nitrogen balance and groundwater nitrate contamination: Comparison among three intensive cropping systems on the North China Plain. Environmental Pollution, 143: 117-125.

MATEO-MARÍN, N., QUÍLEZ, D. and ISLA, R. 2020. Utility of stabilized nitrogen fertilizers to reduce nitrate leaching under optimal management practices. Journal of Plant Nutrition and Soil Science, 183(5): 567-578.

MIRZASHAHI, K., PISHDARFARADANEH, M. and NOURGHOLIPOUR, F. 2010. Effects Different Rates of Nitrogen and Sulphur Application on Canola Yield in North of Khuzestan. Journal of Research in Agricultural Science, 6(2): 107-112.

ÖZTÜRK, Ö. 2010. Effects of source and rate of nitrogen fertilizer on yield, yield components and quality of winter rapeseed (Brassica napus L.). Chilean Journal of Agricultural Research, 70(1): 132-141.

PAWLICK, A. A., WAGNER-RIDDLE, C., PARKIN, G. W. et al. 2019. Assesment of nitrification and urease inhibitors on nitrate leaching in corn (Zea mays L.). Canadian Journal of Soil Science, 99: 80-91.

SANZ-COBENA, A., MISSELBROOK, T., CAMP, V. et al. 2011. Effect of water addition to urease inhibitor NBPT on the abatement of ammonia emission from surface applied urea. Atmospheric Environment, 45: 1517-1524.

SANZ-COBENA, A., SÁNCHEZ-MARTÍN, L., GARCÍA-TORRES, L. et al. 2012. Gaseous emissions of $\mathrm{N}_{2} \mathrm{O}$ and $\mathrm{NO}$ and $\mathrm{NO}_{3}^{-}$leaching from urea applied with urease and nitrification inhibitors to a maize (Zea mays) crop. Agriculture, Ecosystems \& Environment, 149: 64-73.

SINGH, S. N. and VERMA, A. 2007. Environmental Review: The Potential of Nitrification Inhibitors to Manage the Pollution Effect of Nitrogen Fertilizers in Agricultural and Other Soils: A Review. Environmental Practice, 9(4): 266-279.

SPINELLI, D., BARDI, L., FIERRO, A. et al. 2013. Environmental analysis of sunflower production with different forms of mineral nitrogen fertilizers. Journal of Environmental Management, 129: 302-308. 
TRENKEL, M. E. 2010. Slow- and Controlled-Release and Stabilized Fertilizers: An Option for Enhancing Nutrient Efficiency in Agriculture. $2^{\text {nd }}$ Edition. Paris, France: IFA.

VIERO, F., MENEGATI, G. B., CARNIEL, E. et al. 2017. Urease inhibitor and Irrigation Management to Mitigate Ammonia Volatilization from Urea in No-Till Corn. Revista Brasileira de Ciencia do Solo, 41 e0160567.

VILSMEIER, K. 1980. Dicyandiamidabbau im Boden in Abhängigkeit von der Temperatur. Zeitschrift für Pflanzenernährung und Bodenkunde, 143: 113-118.

WOZNIAK, H., MICHEL, H. J. and FUCHS, M. 1999. Nitrification inhibitors for economically efficient and environmental friendly nitrogen fertilization. In: IFA (Ed.). Proceedings of IFA Agricultural Conference on Managing Plant Nutrition. Paris: International Fertilizer Association, pp. 182-194.

ZAMAN, M., NGUYEN, M. L., BLENNERHASSETT, J. D. et al. 2008. Reducing NH3, N2O and NO3-N losses from a pasture soil with urease or nitrification inhibitors and elemental S-amended nitrogenous fertilizers. Biology and Fertility of Soils, 44: 693-705.

Contact information

Dominika Mikusova: dominika.mikusova@mendelu.cz 